\title{
DISTINGUISHING MODES OF LEUKOCYTE CELL DEATH USING FLOW CYTOMETRY IN PATIENTS WITH CHRONIC RHINOSINUSITIS WITHOUT NASAL POLYPS
}

\author{
Anatolii I. Onishchenkol, Anton S. Tkachenkol, Julii M. Kalashnyk2, Pavel M. Zubov³, Tatyana V. Gorbach', \\ Lyubov A. Babijchuk ${ }^{3}$, Oksana A. Nakonechnal \\ ${ }^{1}$ Kharkiv National Medical University, Department of Biochemistry, Kharkiv, Ukraine \\ ${ }_{2}^{2}$ Kharkiv National Medical University, Department of Otorhinolaryngology, Kharkiv, Ukraine \\ 3 Institute for Problems of Cryobiology and Cryomedicine of the National Academy of Sciences of Ukraine, Department of \\ Cryocytology, Kharkiv, Ukraine

\section{RAZLIKOVANJE MODALITETA ĆELIJSKE SMRTI LEUKOCITA KORIŠĆENJEM PROTOČNE CITOMETRIJE KOD BOLESNIKA SA HRONIČNIM RINOSINUZITISOM BEZ NAZALNIH POLIPA}

\author{
Anatolij I. Oniščenko ${ }^{1}$, Anton S. Tkačenko ${ }^{1}$, Julija M. Kalašnik², Pavel M. Zubov³, Tatjana V. Gorbačl, \\ Ljubov A. Babijčuk ${ }^{3}$, Oksana A. Nakonečnal \\ ${ }^{1}$ Nacionalni medicinski univerzitet Harkov, Institut za biohemiju, Harkov, Ukrajina \\ ${ }^{2}$ Nacionalni medicinski univerzitet Harkov, Institut za otorinolaringologiju, Harkov, Ukrajina \\ ${ }^{3}$ Institut za oblast kriobiologije i kriomedicine Nacionalne akademije nauka Ukrajine, Institut za kriocitologiju, Harkov, Ukrajina
}

\section{ABSTRACT}

Objective. The objective of our research is to study the rate and modes of cell death among white blood cells using an Annexin $V$ and 7-AAD flow cytometry kit in patients with chronic rhinosinusitis without nasal polyps (CRSsNP).

Methods. Flow cytometry was used to detect cell death modes of leukocytes in twelve patients with CRSSNP. Annexin $V$ FITC, anti-CD45 PE and 7-AAD (7-aminoactinomycin D) were used for the assessment of apoptosis stages. The current method allows identifying four different states of cells: 1 viable cells (Annexin Vnegative,7-AAD negative cells); 2 early apoptotic cells (AnnexinV positive, 7-AAD negative cells); 3 - late apoptotic/necrotic cells (AnnexinV positive, 7AAD positive cells); 4 - dead necrotic cells (AnnexinV negative, 7-AAD positive cells). To assess the rate of oxidative stress in CRSsNP, 8-isoprostane levels in blood serum were determined using ELISA.

Results. We found that CRSSNP was accompanied by the development of oxidative stress, evidenced by elevation of 8isoprostane in blood serum, and the increased rate of cell death among white blood cells with the prevalence of early apoptotic cells, confirmed by a higher percentage of AnnexinV positive, 7-AAD negative cells compared with control subjects.

Conclusion. Our findings suggest that CRSSNP is accompanied by the activation of leukocyte apoptosis.

Keywords: rhinitis; sinusitis; chronic disease; cell death; apoptosis; necrosis; flow cytometry.

\section{INTRODUCTION}

Chronic rhinosinusitis (CRS) is a long-lasting (over 12 weeks) nasal and paranasal mucosal inflammation characterized by facial pain, nasal obstruction, loss of olfactory function, etc. (1). CRS is one of the frequently diagnosed diseases. Its prevalence depends on geographic regions and may vary. For example, the average value for

\section{SAŽETAK}

Cilj. Cilj našeg istraživanja bio je da se ispitaju brzina $i$ modaliteti ćelijske smrti leukocita pomoću seta protočne citometrije aneksina $V i$ 7-AAD kod pacijenata sa hroničnim rinosinuzitisom bez nazalnih polipa (CRSSNP).

Metode. Za otkrivanje modaliteta ćelijske smrti leukocita kod dvanaest pacijenata sa CRSsNP korišćena je protočna citometrija. Za procenu faza apoptoze korišćeni su aneksin $V$ FITC, anti-CD45 PE $i$ 7-AAD (7-aminoaktinomicin D). Aktuelna metoda omogućava identifikovanje četiri različita stanja ćelija: 1 -vijabilne ćelije (aneksin V negativne, 7-AAD negativne ćelije); 2 - rane apoptotičke ćelije (aneksin $V$ pozitivne, 7-AAD negativne ćelije); 3 - kasne apoptotičkel nekrotične ćelije (aneksin V pozitivne, 7-AAD pozitivne ćelije); 4 - mrtve nekrotične ćelije (aneksin $V$ negativne, 7-AAD pozitivne ćelije). Da bi se procenila stopa oksidativnog stresa u CRSsNP, određivane su koncentracije 8-izoprostana iz krvnog seruma pomoću ELISA.

Rezultati. Ustanovljeno je da je CRSsNP praćen razvojem oksidativnog stresa, pokazano povišenjem 8-izoprostana $u$ krvnom serumu i povećanom stopom ćelijske smrti leukocita sa dominacijom ranih apoptotskih ćelija, što potvrđuje i veći procenat aneksin $V$ pozitivnih, 7-AAD negativnih ćelija $u$ poređenju sa kontrolnim pacijentima.

Zaključak. Nalazi studije sugerišu da CRSsNP prati aktivacija apoptoze leukocita.

Ključne reči: rinitis; sinuzitis; hronična bolest; apoptoza; ćelijska smrt; nekroza; protočna citometrija.

European countries is approximately $11 \%$ (2). Due to its high prevalence, CRS is considered one of the leading causes of short-term disability. This fact determines high CRS-related costs, which reach $\$ 12.5$ billion annually (3).

The disease can be subdivided into two major categories: chronic rhinosinusitis with nasal polyps (CRSwNP) and chronic rhinosinusitis without nasal 
polyps (CRSsNP). The first is accompanied by the formation of noncancerous growths in the sinonasal tract called nasal polyps. The second is not associated with the formation of nasal polyps (4).

Numerous researches have aimed at elucidating the mechanisms that underlie the development of CRS. However, there is no widely recognized theory of both CRSsWP and CRSwNP pathogenesis (5). However, strong evidence suggests that microbial, viral and fungal colonization of upper airways, changes in the nasal microbiome, abnormalities in airway epithelial cell innate immune functions, abnormally functioning mucociliarytransport, imbalance in pro- and anti-inflammatory cytokines and chemokines, extracellular matrix remodeling, epigenetic modifications, epithelial-tomesenchymal transition in nasal epithelial cells and other factors, play an important role in CRS etiopathogenesis (1, 5-9). However, little is known about the role of leukocyte survival/cell deathin the regulation of nasal and paranasal inflammation in CRS despite the role that apoptosis of leukocytes plays in inflammation resolution and opposite pro-inflammatory effects of leukocyte necrosis (10). The role of leukocyte cell death mode in CRS is a relevant topic to study since it affects the course of CRS and determines the intensity of inflammation.

Our research was intended for studying the rate and modes of cell death among white blood cells (WBCs) using anAnnexin $\mathrm{V}$ and 7-AAD flow cytometry kit in patients with CRSsNP.

\section{PATIENTS AND METHODS}

\section{Patients and groups}

Forty patients were enrolled in our study. Twenty of them were recruited from the Otorhinolaryngology Department of the Kharkiv Regional Hospital with the diagnosis of CRSsNP, since they met the criteria for CRSsNP defined in "EPOS 2012: European position paper on rhinosinusitis and NPs 2012" guidelines (11). Twenty individuals were undergoing surgery due to deviated nasal septum. They were chosen as control subjects. Patients were excluded from the experiment if they were diagnosed with other acute or chronic inflammatory diseases, immunodeficiency, immunosuppression, hypertension, chronic cardiovascular diseases, endocrine pathology, cancer, and pregnancy. Twelve patients and ten control subjects were recruited for the flow cytometry analysis, whereas levels of 8-isoprostane were determined in blood serum of all forty individuals enrolled in our research.

\section{Bioethics}

When carrying out the experiment, we strictly followed provisions of the revised Declaration of Helsinki
(2000). The Ethical Committee of Kharkiv National Medical University (Kharkiv, Ukraine) approved the experiment's protocol. A written informed consent was signed by all patients and control subjects who were enrolled in our research.

\section{Flow cytometry}

Flow cytofluorometer FACS Calibur by Becton Dickinson ("BD", USA) was used in our research. Assessment of apoptosis/necrosis stages was carried out by simultaneous addition of Annexin V FITC, anti-CD45 $\mathrm{PE}$ and 7-AAD in accordance with the staining protocol provided by the manufacturer. Five $\mu$ l of Annexin V ( $B D$ Pharmingen, USA), $10 \mu \mathrm{l}$ of 7-AAD (BD Pharmingen, USA) and $10 \mu \mathrm{l}$ of anti-CD45 PE (BD Pharmingen, USA) were added to $50 \mu \mathrm{l}$ of whole blood. Solutions were subsequently gently vortexed and incubated for 15 minutes at room temperature in the dark avoiding exposure to light. 10X Annexin V Binding Buffer containing 0.1 M Hepes/ $\mathrm{NaOH}(\mathrm{pH} 7.4), 1.4 \mathrm{M} \mathrm{NaCl}$ and $25 \mathrm{mM} \mathrm{CaCl}_{2}$ was initially diluted (10X Annexin V Binding Buffer and distilled water in the 1-to-9 ratio) to prepare a $1 \mathrm{X}$ working solution. The $1 \mathrm{X}$ Annexin V Binding Buffer solution was added ( $B D$ Pharmingen, USA) to the samples. We added $400 \mu \mathrm{l}$ of the $1 \mathrm{X}$ Annexin $\mathrm{V}$ Binding Buffer to each sample after the incubation. Samples were analyzed using a cytofluorometer FACS Calibur ("BD", USA) within 30 minutes.

The method was used since it allowed us to identify four different states of cells: 1 - viable cells (AnnexinV negative, 7-AAD negativecells); 2 -early apoptotic cells (AnnexinV positive, 7-AAD negativecells); 3 - late apoptotic/necrotic cells (AnnexinV positive, 7-AAD positive cells); 4 - dead necrotic cells (AnnexinV negative, 7-AAD positive cells).

\section{Evaluation of flow cytometry results}

Evaluation of results was carried out using CELLQuest Pro and WinMDI Version 2.9software. The region of CD45positive cells was chosen for analysis. Gated CD45 positive cells are provided in dot plots in Figure 1.

\section{Assessment of oxidative stress using ELISA}

To assess the rate of oxidative stress, the level of 8isoprostane in blood serum was measured using an ELISA kit manufactured by IBL-Hamburg GmbH (Hamburg, Germany). All procedures were performed according to the instructions provided by the manufacturer. Blood serum concentrations of 8-isoprostane were expressed in $\mathrm{ng} / \mathrm{ml}$.

\section{Statistical analysis}

Statistical analysis was performed using the GraphPad Prism 5software. Kolmogorov-Smirnov test was used to 
test the normality of distribution. Nonparametric MannWhitney U test was used to compare two independent groups. Data are provided as medians and interquartile ranges. A probability of $\mathrm{p}<0.05$ was selected as the level of statistical significance.

\section{RESULTS}

\section{Evaluation of viable leukocytes}

Flow cytometry with Annexin V FITC, CD45 PE and 7-AAD revealed significant changes in the apoptosis rate and modes of apoptosis among leukocytes in patients with CRSsNP compared to healthy subjects from the control group. The disease studied in our research was found to be associated with the statistically significant $(p<0.0001)$ decrease in the amount of viable WBCs whose number was $11.1 \%$ lower in blood of patients with CRSsNP compared to the control group (Figure 1, Table 1). Analysis of results showed that the percentage of early apoptotic, late apoptotic/necrotic and dead necrotic leukocytes in peripheral blood was 3.7-fold higher in patients with CRSsNP compared to healthy individuals. Thus, we can conclude that the rate of cell death among leukocytes in CRSsNP is higher than in the control group.

\section{Assessment of leukocyte cell death modes.}

Analysis of cell death modes revealed significant differences between the two groups. It is interesting to note that the most noticeable changes were observed for AnnexinVpositive, 7-AAD negative cells, i.e. for early apoptotic peripheral leukocytes.CRSsNP was associated with a 5.5-fold increasein the amount of early apoptotic leukocytes compared to the control group (Figure 1, Table 1). The percentage of Annexin $\mathrm{V}$ positive, 7-AAD positive cells was also twice as high in CRSsNP as in healthy subjects, which indicated the increased number of late apoptotic/necrotic WBCs in the patients examined in our research (Figure 1, Table 1). It is worth noting that there were no statistically significant changes in the amount of Annexin V negative, 7-AADpositive cells (dead necrotic cells) between the two groups (Figure 1, Table 1).
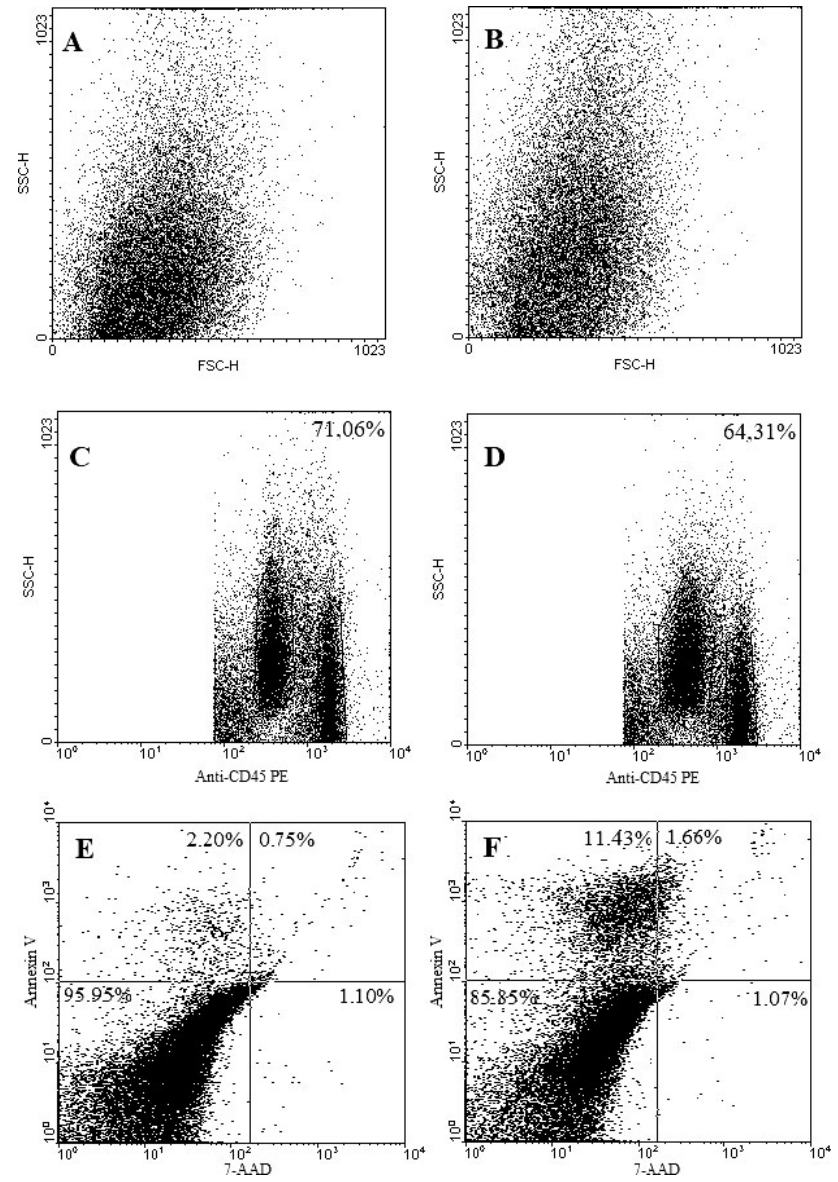

Figure 1. Representative FSC/SSC plots of a healthy individual from the control group $(A)$ and a patient with CRSSNP (B). Representative SSC/CD45 PE dotplots showing gated CD45 positive cells of a healthy subject from the control group $(C)$ and a patient with CRSSNP (D). Both regions of gated $C D 45^{+}$cells were analyzed. The percentage of gated $C D 45^{+}$cells from the total number of events is mentioned. Representative flow cytometric dotplots of viable (Annexin V negative, 7 AAD negative), early apoptotic (Annexin $V$ positive, 7$A A D$ negative), late apoptotic/necrotic (Annexin $V$ positive, 7-AAD positive), and dead necrotic (Annexin $V$ negative, 7-AAD positive) peripheral blood leukocytes are provided. E) A representative dotplot of a healthy subject from the control group; F) A representative dotplot of a patient with CRSsNP. The significant increase $(p<0.0001)$ in the number of early apoptotic (Annexin V positive, 7-AAD negative) cells is observed.

Table 1. The percentage of viable, early apoptotic, late apoptotic/necrotic and dead necrotic cells among peripheral blood leukocytes in patients with CRSSNP.

\begin{tabular}{|l|c|c|c|c|}
\hline Groups & $\begin{array}{c}\text { Annexin V negative, } \\
\text { 7-AAD negative cells } \\
(\text { viable), } \\
\%\end{array}$ & $\begin{array}{c}\text { Annexin V positive, } \\
\text { 7-AAD negative cells } \\
\text { (early apoptotic), } \\
\%\end{array}$ & $\begin{array}{c}\text { Annexin V positive, } \\
\text { 7-AAD positive cells } \\
\text { (late apoptotic/necrotic), } \\
\%\end{array}$ & $\begin{array}{c}\text { Annexin V negative, } \\
\text { 7-AAD positive cells } \\
\text { (dead necrotic cells), } \\
\%\end{array}$ \\
\hline Control group(n=10) & 95.93 & 2.06 & 1.00 & 0.89 \\
& $(95.13 ; 96.89)$ & $(1.65 ; 2.78)$ & $(0.65 ; 1.42)$ & $(0.72 ; 1.08)$ \\
\hline CRSsNP(n=12) & 85.24 & 11.40 & 2.34 & 0.86 \\
& $(82.53 ; 86.85)$ & $(9.89 ; 14.02)$ & $(2.07 ; 3.08)$ & $(0.75 ; 1.11)$ \\
$\mathrm{p}<0.0001$ & $\mathrm{p}<0.0001$ & $\mathrm{p}<0.001$ & $\mathrm{p}>0.05$ \\
\hline
\end{tabular}

Numbers represent the median and $\left(25^{\text {th }}\right.$ percentile; $75^{\text {th }}$ percentile); $p$ is a significance value compared to the control group 


\section{Evaluation of systemic 8-isoprostane levels}

To assess the rate of oxidative stress, we have selected its well-characterized marker 8-isoprostane. Its determination in blood serum of patients with CRSsNP showed a significant increase in the level of this oxidative stress marker $(\mathrm{p}<0.0001)$. The concentrations of 8 isoprostane in patients with CRSsNP reached 4.84(3.89; $6.67) \mathrm{ng} / \mathrm{ml}$, whereas in the control group the levels of 8isoprostane were $2.16(1.16 ; 2.78) \mathrm{ng} / \mathrm{ml}$ (Figure 2).

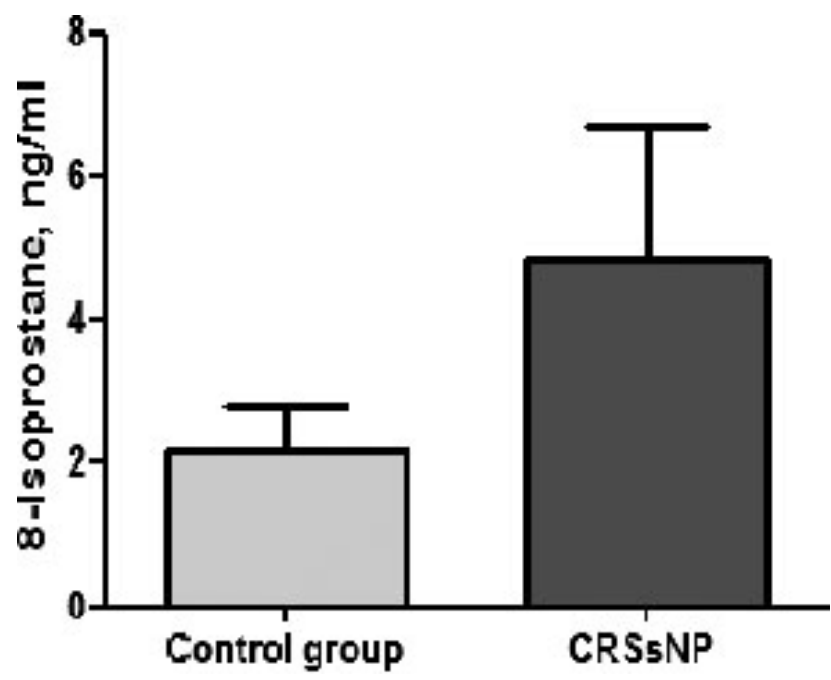

Figure 2. Systemic concentrations of 8-isoprostane in patients with CRSsNP and control subjects. The statistically significant $(p<0.0001)$ increase in 8 -

isoprostane levels in patients with CRSsNP compared to the control subjects indicates the development of oxidative stress.

\section{DISCUSSION}

Cell death is of extreme importance for the regulation of homeostasis in multicellular organisms. Several modes of cell death have been reported, including apoptosis, necrosis, and recently discovered pyroptosis and necroptosis (12-14). Necrosis and apoptosis seem to be major and the most characterized modes of cell death. The two modes of cell death mentioned above are frequently contrasted to each other due to their different roles in regulation of pathological processes. For instance, necrotic cell death is believed to provoke inflammation and contributes to the intensification of the inflammatory response, whereas apoptosis is not associated with the rupture of the membrane and the release of the cell content. Thus, apoptosis does not trigger the inflammatory response $(15,16)$.

The survival and cell death of leukocytes, which depend on the combination of various pro-apoptotic and anti-apoptotic stimuli from the microenvironment of the cells, are important for the regulation of inflammation, since the intensity of inflammation is maintained by the balance between the recruitment and removal of new immune cells. Thus, apoptosis is necessary for removal of immunocompetent cells, their functional shutdown, and resolution of the inflammatory process (17).

In our opinion, the increased rate of leukocyte apoptosis observed in the patients with CRSsNP aims at preventing the damage to host tissues and promoting the resolution of the inflammatory process.

The increase in the percentage of Annexin $\mathrm{V}$ positive, 7-AAD negative cells in CRSsNP may be attributed to the PS externalization, which is a sign of early apoptosis. Such loss of plasma membrane phosphatidylserine asymmetry is a hallmark of apoptosis and can develop as a result of the action of several factors. Under normal circumstances, the phospholipid transbilayer asymmetry is maintained by the action of aminophospholipid translocase (APT) and ATP-dependent scramblase. PS translocation from the inner leaflet to the outer layer of the cell membrane requires inhibition of the former and activation of the latter (18). It is interesting to note that apoptosis is associated with selective oxidation of phosphatidylserine $(18,19)$. PS oxidation occurs before its externalization in apoptosis. Thus, oxidized PS cannot be recognized by APT, causing its failure to transfer it back to the cytosolic leaflet.

Having found the significantly elevated level of 8isprostane, which is a product of free radical-catalyzed peroxidation of arachidonic acid and therefore a marker of oxidative stress, in blood serum of patients with CRSsNP, we have concluded that the disease is accompanied with the development of oxidative stress and activation of free radical processes (20). Our results are consistent with numerous studies that confirm the overproduction of reactive oxygen species and development of oxidative stress in chronic rhinosinusitis (21-23). We believe that PS externalization can partially be due to the direct influence of reactive oxygen species on the molecules of PS, and oxidatively modified PS molecules cannot be translocated to the inner leaflet, causing Annexin $\mathrm{V}$ binding. In addition to its direct impact on phospholipid bilayer, oxidative stress may induce apoptosis by the mitochondriadependent and mitochondria-independent pathways (24). The former is accompanied by the cytochrome $\mathrm{c}$ release. It is believed that cytochrome contributes to the oxidation and translocation of PS to the outer layer of cell membranes $(25,26)$. The impact of cytochrome $\mathrm{c}$ on PS externalization and further apoptosis may be explained by its ability to catalyze PS oxidation due to its peroxidase activity $(25,27)$. Thus, the high percentage of early apoptotic WBCs in patients with CRSsNP compared to the control group may be associated with oxidative stress that contributes to the activation of apoptosis in several ways. 
Our research also showed that CRSsNP was accompanied by an increase in the percentage of late apoptotic/necrotic leukocytes. However, the amount of such cells was much lower compared to leukocytes at the early stage of apoptosis. Early apoptotic cells can become late apoptotic or necrotic when their plasma membrane loses its integrity and becomes permeable, which can be judged from the fluorescence of 7-AAD. This dye has strong affinity for double-stranded DNAand intercalates in GC-rich regions (28). The access to DNA is provided only when membranes are not intact and their permeability increases, indicating late apoptosis or necrosis. We can presume that the quite low amount of late apoptotic/necrotic leukocytes against the background of the fairly high percentage of early apoptotic cells may be attributed to the persistence of cells due to an overload of dying cells and their less efficient engulfment by phagocytic cells. Thus, early apoptotic leukocytes partially undergo secondary necrosis in patients with CRSsNP. However, the percentage of leukocytes underwent secondary apoptosis does not seem to be high in patients suffering from CRSsNP, indicating that the bulk of early apoptotic cells are removed by phagocytosis. Since there is strong evidence that the removal of cells at the early stage of apoptosis has anti-inflammatory effects due to an increase in the formation of anti-inflammatory cytokines against the background of the decreased production of pro-inflammatory cytokines (29), we believe that the results of flow cytometry obtained in our research indicate the significant uptake of early apoptosis cells by phagocytes to decrease the rate of inflammation and damage to own tissues.

\section{LIST OF ABBREVIATIONS}

7-AAD - 7-aminoactinomycin D

APT - aminophospholipid translocase

CRSsNP - chronic rhinosinusitis without nasal polyps

FLICA - fluorochrome-labeled inhibitors of caspases

PARP - poly (ADP-ribose) polymerase

PS - phosphatidylserine

\section{REFERENCES}

1. Kim JY, Kim DK, Yu MS, Cha MJ, Yu SL, Kang J. Role of epigenetics in the pathogenesis of chronic rhinosinusitis with nasal polyps. Mol Med Rep 2018; 17: 1219-27.

2. Beule A. Epidemiology of chronic rhinosinusitis, selected risk factors, comorbidities, and economic burden. GMS Curr Top Otorhinolaryngol Head Neck Surg 2015; 14: Doc11. (doi: 10.3205/cto000126).
3. Yip J, Vescan AD, Witterick IJ, Monteiro E. The personal financial burden of chronic rhinosinusitis: a Canadian perspective. Am J Rhinol Allergy 2017; 31: 216-21.

4. Dennis SK, Lam K, Luong A. A review of classification schemes for chronic rhinosinusitis with nasal polyposis endotypes. Laryngoscope Investig Otolaryngol 2016; 1: 130-4.

5. Lam K, Schleimer R, Kern RC. The etiology and pathogenesis of chronic rhinosinusitis: a review of current hypotheses. Curr Allergy Asthma Rep 2015; 15: 41. (doi: 10.1007/s11882-015-0540-2).

6. Onishchenko AI, Lupyr AV, Tkachenko AS, Gorbach TV, Nakonechna OA, GubinaVakulyck GI. Epithelialto-mesenchymal transition and some parameters of extracellular matrix remodeling in chronic rhinosinusitis with nasal polyps. HVM Bioflux 2018; 10: $128-32$.

7. Konig K, Klemens C, Haack M, et al. Cytokine patterns in nasal secretion of non-atopic patients distinguish between chronic rhinosinusitis with or without nasal polys. Allergy Asthma Clin Immunol 2016; 12: 19. (doi: 10.1186/s13223-016-0123-3).

8. Kostamo K, Toskala E, Tervahartiala T, Sorsa T. Role of matrix metalloproteinases in chronic rhinosinusitis. Curr Opin Allergy Clin Immunol 2008; 8: 21-7.

9. Baroody FM. Mucociliary transport in chronic rhinosinusitis. Clin Allergy Immunol 2007; 20: 103-19.

10. Ortega-Gómez A, Perretti M, Soehnlein O. Resolution of inflammation: an integrated view. EMBO Mol Med 2013; 5: 661-74.

11. Fokkens WJ, Lund VJ, Mullol J, et al. EPOS 2012: European position paper on rhinosinusitis and nasal polyps 2012. A summary for otorhinolaryngologists. Rhinology 2012; 50: 1-12.

12. Liu C, Zhang K, Shen H, Yao X, Sun Q, Chen G. Necroptosis: a novel manner of cell death, associated with stroke (Review). Int J Mol Med 2018; 41: 624-30.

13. Sendler M, Mayerle J, Lerch MM. Necrosis, apoptosis, necroptosis, pyroptosis: it matters how acinar cells die during pancreatitis. Cell Mol Gastroenterol Hepatol 2016; 2: 407-8.

14. Gunther C, Neumann H, Neurath MF, Becker C. Apoptosis, necrosis and necroptosis: cell death regulation in the intestinal epithelium. Gut 2013; 62: 1062-71.

15. Wallach D, Kovalenko A. Keeping inflammation at bay. Elife 2014; 3: e02583. (doi: 10.7554/eLife.02583).

16. Nikoletopoulou V, Markaki M, Palikaras K, Tavernarakis N. Crosstalk between apoptosis, necrosis and autophagy. Biochim Biophys Acta 2013; 1833: 3448-59. 
17. El Kebir D, Filep JG. Modulation of Neutrophil apoptosis and the resolution of inflammation through $\beta 2$ integrins. Front Immunol 2013; 4: 60. (doi: 10.3389/fimmu.2013.00060).

18. Kagan VE, Fabisiak JP, Shvedova AA, et al. Oxidative signaling pathway for externalization of plasma membrane phosphatidylserine during apoptosis. FEBS Lett 2000; 477: 1-7.

19. Fabisiak JP, Tyurina YY, Tyurin VA, Kagan VE. Quantification of selective phosphatidylserine oxidation during apoptosis. Methods Mol Biol 2014; 1105: 603-11.

20. Ogawa F, Shimizu K, Muroi E, et al. Serum levels of 8 -isoprostane, a marker of oxidative stress, are elevated in patients with systemic sclerosis. Rheumatology (Oxford) 2006; 45: 815-8.

21. Stevens WW, Lee RJ, Schleimer RP, Cohen NA. Chronic rhinosinusitis pathogenesis. J Allergy Clin Immunol 2015; 136: 1442-53.

22. Fordham MT, Mulligan JK, Casey SE, et al. Reactive oxygen species in chronic rhinosinusitis and secondhand smoke exposure. Otolaryngol Head Neck Surg 2013; 149: 633-8.

23. Cekin E, Ipcioglu OM, Erkul BE, et al. The association of oxidative stress and nasal polyposis. J Int Med Res 2009; 37: 325-30.
24. Sinha K, Das J, Pal PB, Sil PC. Oxidative stress: the mitochondria-dependent and mitochondriaindependent pathways of apoptosis. Arch Toxicol 2013; 87: 1157-80.

25. Yamashita A, Morikawa H, Tajima N, et al. Mechanisms underlying production and externalization of oxidized phosphatidylserine in apoptosis: involvement of mitochondria. Yonago Acta Med 2012; 55: 11-20.

26. Jiang J, Serinkan BF, Tyurina YY, et al. Peroxidation and externalization of phosphatidylserine associated with release of cytochrome c from mitochondria. Free Radic Biol Med 2003; 35: 814-25.

27. Bayir H, Fadeel B, Palladino MJ, Witasp E, Kurnikov IV, Tyurina YY. Apoptotic interactions of cytochrome c: redox flirting with anionic phospholipids within and outside of mitochondria. Biochim Biophys Acta 2006; 1757: 648-59.

28. Zembruski NC, Stache V, Haefeli WE, Weiss J. 7Aminoactinomycin D for apoptosis staining in flow cytometry. Anal Biochem 2012; 429: 79-81.

29. Poon IK, Hulett MD, Parish CR. Molecular mechanisms of late apoptotic/necrotic cell clearance. Cell Death Differ 2010; 17: 381-97. 